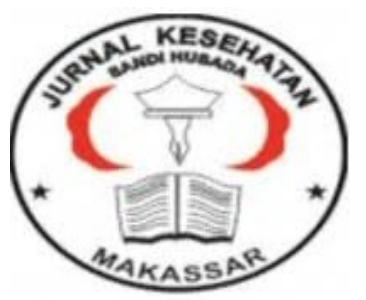

\author{
Jurnal Ilmiah Kesehatan Sandi Husada
}

hhttps://akper-sandikarsa.e-journal.id/JIKSH

Vol 11, No, 1, Juni 2020, pp; 164-169

p-ISSN: 2354-6093 dan e-ISSN: 2654-4563

DOI: $10.35816 /$ jiskh.v10i2.237

\title{
Kebiasaan Sarapan Pagi dengan Prestasi Belajar Siswa SD Negeri 01 Rajabasa Bandar Lampung
}

The Morning Habits with Student Achievement in Elementary School 01 Rajabasa Bandar Lampung

\author{
Ringgo Alfarisi' ${ }^{1}$, Yuniastini ${ }^{2}$, Astri Pinilih ${ }^{3}$ Putri Nur Oktavia Jauhari ${ }^{4}$ \\ 1Departemen Fakultas Kedokteran Universitas Malahayati \\ 2Departemen Fakultas Kedokteran Universitas Malahayati \\ ${ }^{3}$ Departemen Ilmu Kesehatan Anak Fakultas Kedokteran Universitas Malahayati \\ ${ }^{4}$ Mahasiswa Program Studi Kedokteran Universitas Malahayati
}

\begin{tabular}{l}
\multicolumn{1}{c}{ Artikel info } \\
\hline \hline \\
Artikel history: \\
Received; 17 Maret 2020 \\
Revised:20 Maret 2020 \\
Accepted;21 Maret 2020
\end{tabular}

\begin{abstract}
Abstrak.
Latar Belakang: Latar Belakang: Energi yang adekuat pada saat sarapan pagi diperlukan untuk menunjang aktivitas belajar khusunya bagi anak sekolah. Energi diperoleh dari makanan atau minuman yang dikonsumsi oleh masing-masing anak. Anak yang seringkali melewatkan sarapan sangat tidak dianjurkan. Melewatkan sarapan membuat anak tidak berenergi karena perut kosong sehingga anak menjadi susah untuk memfokuskan pikiran di sekolah. Hal tersebut sangat tidak mendukung dalam peningkatan prestasi belajar. Tujuan Penelitian: Untuk mengetahui adakah hubungan kebiasaan sarapan pagi dengan prestasi belajar pada siswa-siswi Sekolah Dasar Negeri 01 Rajabasa di Bandar Lampung. Metode Penelitian: Jenis penelitian ini adalah penelitian kuantitatif dengan pendekatan cross sectional. Pengambilan sampel menggunakan teknik purposive sampling. Analisis bivariat yang digunakan adalah uji Chi Square. Hasil Penelitian: Dengan jumlah sampel sebanyak 60 responden, responden dengan sarapan pagi tidak rutin didapatkan 12 siswa, dimana 8 siswa $(66,7 \%)$ prestasi belajar dibawah rata-rata dan $4 \quad(33,3 \%)$ siswa prestasi belajar diatas rata-rata. Kemudian, responden yang sarapan pagi rutin didapatkan 48 siswa, dimana 6 siswa $(12,5 \%)$ prestasi belajar dibawah rata-rata, dan 42 siswa $(76,0 \%)$ prestasi belajar diatas ratarata. Berdasarkan hasil uji fisher exact test hasil penelitian menunjukkan nilai $\mathrm{p}$ value sebesar $0,000(\leq 0,05)$ yang berarti bahwa sarapan pagi dengan rutin mendukung dalam peningkatan prestasi belajar siswa OR $=14$. Kesimpulan : Terdapat hubungan yang signifikan antara kebiasaan sarapan pagi dengan prestasi belajar siswa-siswi SDN 01
\end{abstract}


Rajabasa Bandar Lampung. Kata Kunci : Prestasi belajar, Sarapan pagi.

Abstract

Background: Background:Adequate energy at breakfast time is needed to support learning activities especially for school children. Energy obtained from food or beverages consumed by each child. Kids who skip breakfast often is not recommended. Skipping breakfast makes children not energized because an empty stomach so that the child becomes difficult to focus the mind in school. It is very supportive in improving learning achievement. Purposes: To know is there any relation morning breakfast habits and academic achievement in students of State Elementary School 01 Rajabasa in Bandar Lampung. Methods: This type of research is quantitative research with cross sectional approach. Sampling using purposive sampling technique. The bivariate analysis used was Chi Square test. Result: With a total sample of 60 respondents, respondents with a full breakfast is not routinely obtained 12 students, of which 8 students (66.7\%) of learning achievement is below average and 4 (33.3\%) of students' learning achievement is above average. Then, the respondents who eat breakfast regularly gained 48 students, of which 6 students (12.5\%) of learning achievement is below average, and 42 students (76.0\%) of learning achievement is above average. Based on the test results Fisher exact test results showed $p$ value of 0.000 $(\leq 0,05)$ which means that breakfast was served with regular support increased student achievement $O R=14$. Conclusion: There is a significant relationship between breakfast habits and academic achievement students of State Elemntary School 01 Rajabasa in Bandar Lampung.

Keywords:

Breakfast;

Academic Achievement;
Coresponden author: Email: jauhari405@gmail.com

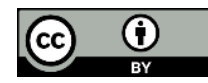

artikel dengan akses terbuka dibawah lisensi CC BY -4.0

\section{Pendahuluan}

Anak adalah harapan masa depan bagi bangsa dan keluarga, maka perlu dipersiapkan agar kelak menjadi sumber daya manusia yang berkualitas, bermoral, sehat serta dapat berguna bagi masyarakat. Bangsa yang maju adalah bangsa yang memiliki tingkat kecerdasan, kesehatan, dan produktivitas kerja yang tinggi, ketiga hal ini dipengaruhi oleh keadaan gizi. Pola makan yang baik merupakan perilaku paling penting yang dapat mempengaruhi keadaan gizi. 
Keterlambatan asupan gizi di pagi hari dapat membuat tubuh lemah, lesu, pusing, dan menurunkan konsentrasi berfikir dan belajar Hardinsyah (2018). Hal ini disebabkan karena kuantitas dan kualitas makanan dan minuman yang dikonsumsi akan mempengaruhi tingkat kesehatan individu dan masyarakat. Berkaitan dengan gizi maka, pola makan masyarakat perlu ditingkatkan kearah konsumsi gizi seimbang (Kementrian Kesehatan RI, 2014).

Menurut (Hardinsyah, 2018) makan pagi atau sarapan mempunyai peranan penting bagi anak sekolah usia 6-12 tahun, yaitu untuk pemenuhan gizi di pagi hari, dimana anak-anak berangkat kesekolah dan mempunyai aktivitas yang sangat padat di sekolah. Apabila anakanak terbiasa sarapan pagi, maka akan berpengaruh terhadap kecerdasan otak, terutama daya ingat anak. Karena dapat mendukung konsentrasi sehingga berpengaruh pada prestasi belajar anak disekolah. Sarapan pagi merupakan pasokan energi untuk otak yang paling baik agar dapat berkonsentrasi di sekolah. Ketika bangun pagi, gula darah dalam tubuh kita rendah karena semalaman tidak makan. Tanpa sarapan yang cukup, otak akan sulit berkonsentrasi di sekolah. Oleh karenanya bagi anak sekolah, kebiasaan sarapan pagi bisa membantu memenuhi kecukupan gizinya sehari-hari. Jenis hidangan untuk sarapan pagi bisa dipilih dan disusun sesuai keadaan. Namun akan lebih baik bila terdiri dari makanan sumber zat tenaga, sumber zat pembangun dan sumber zat pengatur (Hartoyo, 2016).

Energi yang adekuat diperlukan untuk menunjang aktivitas belajar khusunya bagi anak sekolah. Energi diperoleh dari makanan atau minuman yang dikonsumsi oleh masingmasing anak. Anak yang seringkali melewatkan sarapan sangat tidak dianjurkan. Melewatkan sarapan membuat anak tidak berenergi karena perut kosong sehingga anak menjadi susah untuk memfokuskan dalam mengikuti pelajaran di sekolah. Menurut (Verdiana dkk, 2017) dalam pemenuhan kebutuhan gizi anak, konsumsi sarapan berpengaruh positif untuk peningkatan kualitas diet, asupan mikronutrien, status berat badan dan faktor gaya hidup. Sarapan dianjurkan karena dapat mempengaruhi peningkatan pembelajaran pada anak-anak dalam hal perilaku, kognitif, dan prestasi belajar anak di sekolah (Iqbal, 2015). Melalui penelitian Iqbal (2015) dalam penelitiannya yang dilaksanakan pada bulan Januari 2015 di SD Negeri 1 Karangasem Surakarta didapatkan bahwa terdapat hubungan antara kebiasaan sarapan pagi dan prestasi belajar anak sekolah dasar. Namun dalam penelitian Noviyanti (2018) yang dilaksanakan pada bulan Mei 2018 di SD Muhammadiyah Surakarta dia menyebutkan bahwa hasil kesimpulan dari penelitiannya yaitu tidak terdapat hubungan kebiasaan sarapan pagi dengan prestasi belajar siswa sekolah dasar.

Berdasarkan uraian diatas, mengingat terdapat perbedaan hasil penelitian tentang kebiasaan sarapan pagi dengan prestasi belajar dari kedua peneliti tersebut, sehingga peneliti tertarik untuk melakukan penelitian yang berjudul Hubungan Kebiasaan Sarapan Pagi dengan Prestasi Belajar pada Siswa-Siswi Sekolah Dasar 01 Rajabasa di Bandar lampung. Untuk mengetahui apakah ada hubungan sarapan pagi dengan prestasi belajar siswa disekolah tersebut. Mengingat pentingnya pengetahuan tentang sarapan pagi bagi siswa, orangtua maupun guru disekolah sehingga turut meningkatkan pertumbuhan anak yang baik dalam lingkungan yang sehat dan menciptakan generasi penerus bangsa yang berkualitas dan berpotensi. 


\section{Metode}

Jenis penelitian ini adalah penelitian kuantitatif dengan pendekatan cross sectional. Pengambilan sampel menggunakan teknik purposive sampling. Analisis bivariat yang digunakan adalah uji Chi Square. Penelitian ini dilakukan pada siswa-siswi kelas 6 di Sekolah Dasar Negeri 01 Rajabasa di Bandar Lampung tahun ajaran 2019-2020. Dengan metode wawancara pada kebiasaan sarapan pagi dan prestasi belajar menggunakan data nilai rata-rata raport siswa di sekolah tersebut, Dengan jumlah sampel sebanyak 60 responden kondisi sehat dan sesuai dengan karakteristik sampel.

\section{Hasil Dan Pembahasan}

Tabel 1. Analisis Kebiasaan Sarapan Pagi dengan Prestasi Belajar Siswa-Siswi SDN 01 Rajabasa Bandar Lampung Tahun Ajaran 2019-2020.

\begin{tabular}{rcccccc}
\hline & & \multicolumn{3}{c}{ Prestasi Belajar } & \multirow{2}{*}{ Nilai } & OR \\
\cline { 3 - 5 } & & $\begin{array}{c}\text { Dibawah } \\
\text { rata-rata }\end{array}$ & $\begin{array}{c}\text { Diatas rata- } \\
\text { rata }\end{array}$ & Total & p & \\
\hline \multirow{3}{*}{ Sarapan Pagi } & Tidak & 8 & 4 & 12 & & \\
\cline { 2 - 5 } & Rutin & $66,7 \%$ & $33,3 \%$ & $100 \%$ & 0,000 & \multirow{2}{*}{14} \\
\cline { 2 - 6 } & \multirow{2}{*}{ Rutin } & 6 & 42 & 48 & & \\
\hline \multirow{2}{*}{ Total } & $12,5 \%$ & $87,5 \%$ & $100 \%$ & & \\
& & 14 & 46 & 60 & & \\
\hline
\end{tabular}

Berdasarkan di atas, siswa kelas 6 dengan sarapan pagi tidak rutin didapatkan 12 siswa, dimana 8 siswa $(66,7 \%)$ prestasi belajar dibawah rata-rata dan $4(33,3 \%)$ siswa prestasi belajar diatas rata-rata. Kemudian, siswa kelas 6 yang sarapan pagi rutin didapatkan 48 siswa, dimana 6 siswa (12,5\%) prestasi belajar dibawah rata-rata, dan $42(76,0 \%)$ prestasi belajar diatas rata-rata. Berdasarkan hasil uji fisher exact test hasil penelitian menunjukkan nilai p value sebesar $0,000(\leq 0,05)$ yang berarti bahwa terdapat hubungan yang signifikan antara kebiasaan sarapan pagi dengan prestasi belajar siswa-siswi SDN 01 Rajabasa Bandar Lampung.

Berdasarkan penelitian yang dilakukan di SDN 01 Rajabasa Bandar Lampung setelah di analisis dengan uji Chi Square menunjukan hubungan yang signifikan dimana nilai $\mathrm{p}=0.000$ dan batas bermakna nilai $\mathrm{p}<0.05$ maka terdapat hubungan antara kebiasaan sarapan pagi dan prestasi belajar. Hasil penelitian ini sejalan dengan pendapat Iqbal (2015) bahwa pada penelitiannya terdapat hubungan yang bermakna antara kebiasaan sarapan pagi dan prestasi belajar anak sekolah dasar. Menurut penelitian (Isnaini, 2017) sarapan pagi berperan penting dalam memenuhi kebutuhan energi anak sekolah, karena dapat meningkatkan konsentrasi belajar dan memudahkan menyerap pelajaran di sekolah, sehingga prestasi belajar menjadi baik. Pada umumnya sarapan pagi memberikan kontribusi energi sebesar $25 \%$ dari kebutuhan gizi sehari. Selama proses pencernaan, karbohidrat di dalam tubuh dipecah menjadi molekul gula sederhana, seperti fruktosa, galaktosa dan glukosa. Glukosa merupakan bahan bakar otak sehingga membantu dalam mempertahankan konsentrasi, meningkatkan kewaspadaan, dan memberi kekuatan untuk otak.

Sejalan dengan penelitian Hardinsyah (2018) meta analisis terhadap 41 penelitian tentang sarapan menunjukkan bahwa performa akademik (prestasi belajar) pada anak dan remaja yang memperoleh sarapan lebih baik dibanding yang tidak sarapan. Studi meta analisis selanjutnya oleh Adolphus (2013) dalam Anwar (2018) menunjukkan hubungan yang 
positif antara sarapan dengan penyeselaian tugas-tugas pembelajaran di kelas dan performa akademik terutama pada nilai matematika dan aritmatika pada anak-anak yang kurang gizi. Peningkatan kebiasaan sarapan juga meningkatkan performa akademik anak sekolah. Jadi, sarapan dapat meningkatkan prestasi belajar.

Hal ini juga sesuai dengan Hasil penelitian Auliana, (2012) dalam Rahma (2016) mengatakan bahwa untuk mengoptimalkan pertumbuhan fisik, perkembangan otak, kepandaian, dan kematangan sosial diperlukan komposisi seimbang antara karbohidrat (45\%-65\%), protein (10\%25\%), lemak (30\%), dan berbagai macam vitamin lain. Oleh karenanya, di pagi hari setelah seseorang tidak mengkonsumsi makanan selama 12 jam, kadar gula darah dalam tubuh menjadi menurun. Padahal, glukosa dalam darah adalah satu-satunya penyuplai energi bagi otak untuk bekerja secara optimal. Bila glukosa darah anak rendah, apalagi sampai di bawah $70 \mathrm{mg} / \mathrm{dl}$ (hipoglekemia), maka akan terjadi penurunan konsentrasi belajar, tubuh menjadi melemah, pusing dan gemetar. Selain itu, jika dibandingkan dengan organ tubuh lainnya, otak adalah pengguna energi terbesar dalam tubuh manusia (Rahma, 2016). Prestasi belajar penting bagi siswa, karena prestasi belajar akan menentukan kemampuan siswa dan menentukan naik tidaknya siswa ketingkat yang lebih tinggi. Slameto (2010) menyatakan bahwa prestasi adalah bukti keberhasilan usaha yang dapat dicapai. Salah satu cara menilai kualitas seorang anak dengan melihat prestasi belajarnya di sekolah. Sarapan pagi berperan penting dalam memenuhi kebutuhan energi anak sekolah, karena dapat meningkatkan konsentrasi belajar dan memudahkan menyerap pelajaran di sekolah, sehingga prestasi belajar menjadi baik.

Sarapan pagi sangat bermanfaat bagi setiap orang. Menurut Erlyningrum (2019) bahwa sarapan pagi sangat bermanfaat bagi orang dewasa untuk mempertahankan ketahanan fisik, sedangkan bagi anak-anak sekolah untuk meningkatkan kemampuan belajar. Tidak makan pagi bagi anak sekolah menyebabkan kurangnya kemampuan untuk konsentrasi belajar, menimbulkan rasa lelah dan mengantuk. Seseorang yang tidak makan pagi memiliki risiko menderita gangguan kesehatan yaitu menurunnya kadar gula dengan tanda-tanda antara lain: lemah, keluar keringat dingin, kesadaran menurun, pingsan. Bagi anak sekolah, kondisi ini menyebabkan menurunnya konsentrasi belajar yang mengakibatkan menurunnya prestasi belajar.

\section{Simpulan Dan Saran}

Berdasarkan hasil penelitian yang dilakukan, dapat diambil kesimpulan sebagai berikut: Mayoritas siswa SDN 01 Rajabasa Bandar Lampung yaitu dalam kategori rutin sarapan pagi $(80,0 \%)$ siswa dan prestasi belajarnya diatas atau sama dengan rata-rata yaitu sejumlah (76,7\%).Terdapat hubungan yang signifikan antara kebiasaan sarapan pagi dengan prestasi belajar siswa-siswi SDN 01 Rajabasa di Bandar Lampung $(p=0,000)$ dengan OR : 14.

Diharapkan dapat melakukan penelitian lebih lanjut mengenai faktor-faktor lain yang berhubungan dengan prestasi belajar seperti faktor internal dan eksternal. Faktor internal terdiri dari faktor fisiologis (jasmani) dan psikologis. Faktor fisiologis (jasmani) yaitu kondisi fisiologis siswa seperti status gizi yang juga dipengaruhi oleh kebiasaan sarapan pagi, persediaaan pangan keluarga, pola konsumsi makanan keluarga, zat gizi dalam makanan serta pendapatan keluarga. Faktor psikologis yaitu terdiri dari intelegensi, minat, bakat, dan motivasi. Faktor ekterna terdiri dari orang tua, sarana dan prasarana, lingkungan, media pembelajaran, dan metode belajar yang kurang tepat. Dan juga diharapkan dapat menambah besar sampel untuk membantu dalam melakukan penelitian yang lebih mendalam. 


\section{Daftar Rujukan}

Erlyningrum, D., 2019 Hubungan Antara Kebiasaan Sarapan Pagi Dengan Prestasi Belajar Pada Siswa Sekolah Dasar Negeri Duren Kecamatan Bandungan Kabupaten Semarang. Badan Penerbit Politeknik Kesehatan Semarang.

Hanif, E.S., Hubungan Sarapan Dengan Prestasi Belajar Pada Mahasiswa Semester 2 Pada Modul BSN III UIN Syarif Hidayatullah Jakarta 2016 (Bachelor's thesis, UIN Syarif Hidayatullah Jakarta: Fakultas Kedokteran dan Ilmu Kesehatan, 2016).

Hardinsyah, \& Anwar, k. (2018) Mitos Dan Fakta Sarapan. Bogor : PERGIZI PANGAN Indonesia dan Departemen Gizi Masyarakat FEMA IPB.

Hardinsyah, H. and Aries, M., 2012. Jenis Pangan Sarapan Dan Perannya Dalam Asupan Gizi Harian Anak usia 6-12 Tahun Di Indonesia. Jurnal Gizi dan Pangan, 7(2), pp.89-96.

Hartoyo, E, Sholihah, Q, Fauzia, R, dan Rachma, D. (2015) Sarapan Pagi Dan Produktivitas, Malang : Universitas Brawijaya press ( UB Press).

http://pergizi.org. Diakses tanggal 9 Januari 2013.

Iqbal, F.M., 2015. Hubungan Antara Kebiasaan Sarapan Pagi Dan Prestasi Belajar Anak Sekolah Dasar (Doctoral dissertation, Universitas Muhammadiyah Surakarta).

Isnaini, W., 2017. Hubungan Motivasi Belajar Dengan Prestasi Belajar Siswa Kelas V Sd Negeri 1 Waringinsari Barat Kabupaten Pringsewu. Skripsi. Diterbitkan. Universitas Lampung.

Kalsum, U. and Halim, R., 2016. Kebiasaan Sarapan Pagi Berhubungan Dengan Kejadian Anemia pada Remaja di SMA Negeri 8 Muaro Jambi. Jurnal Penelitian Universitas Jambi: Seri Sains, 18(1).

Noviyanti, R.D. and Kusudaryati, D.P.D., 2018. Hubungan Kebiasaan Sarapan Pagi Dengan Prestasi Belajar Siswa SD Muhammadiyah Program Khusus Surakarta. Profesi (Profesional Islam): Media Publikasi Penelitian, 16(1), pp.72-77.

Rahma, F., 2016. Hubungan Antara Kebiasaan Sarapan Pagi Dengan Prestasi Belajar Siswa Sdn Sawahan I/340 Surabaya. AntroUnairdotNet. 5 (3), 576.

RI, K.K., 2014. Peraturan Menteri Kesehatan Republik Indonesia nomor 41 tahun 2014 Tentang Pedoman Gizi Seimbang. Kementerian Kesehatan Republik Indonesia. Jakarta.

Riskesdas, R.I., 2010. Profil Kesehatan Indonesia 2010 Menuju Indonesia sehat. Departemen Kesehatan RI: Jakarta.

Slameto, B., 1988. Faktor-Faktor Yang Mempengaruhinya, Jakarta: PT. Bina Aksara.

Verdiana, L. and Muniroh, L., 2018. Kebiasaan Sarapan Berhubungan Dengan Konsentrasi Belajar Pada Siswa SDN Sukoharjo I Malang. Media Gizi Indonesia, 12(1), pp.14-20. 